\title{
Conserving original in situ diversity in microzooplankton grazing set-ups
}

\author{
MARTIN GÜNTER JOACHIM LÖDER ${ }^{1}$, NICOLE ABERLE ${ }^{1}$, CHRISTINE KLAAS ${ }^{2}$, \\ ALEXANDRA CLAUDIA KRABERG ${ }^{1}$ AND KAREN HELEN WILTSHIRE ${ }^{1}$ \\ ${ }^{1}$ Biologische Anstalt Helgoland, Alfred-Wegener-Institute for Polar and Marine Research, Marine Station, POB 180, 27483 \\ Helgoland, Germany, ${ }^{2}$ Alfred-Wegener-Institute for Polar and Marine Research, POB 12 o1 61, 27515 Bremerhaven, Germany
}

\begin{abstract}
Grazing experiments targeting the determination of in situ grazing rates are standard. In two separate experiments the effect of the frequently used siphon filling technique on the abundance of microzooplankton during the set-up of grazing experiments was investigated and compared to results from an alternative filling method. Hereby, water containing natural communities from Helgoland Roads, Germany $\left(54^{\circ} 11.3^{\prime} \mathrm{N} 7^{\circ} 54.0^{\prime} \mathrm{E}\right)$, was transferred into incubation bottles using a funnel system (funnel-transfer technique (FTT)). The impact of pre-screening with a $200 \mu \mathrm{m}$ net for excluding larger mesozooplankton grazers from the incubations was evaluated. Results show that the ciliate community was strongly affected by siphoning and pre-screening, leading to significant differences in abundance and Margalef diversity. The most affected ciliates were Lohmanniella oviformis and Myrionecta rubra, both important species in the North Sea. Dinoflagellates did not show any significant response to either siphoning or pre-screening with the exception of one athecate species. Such artificial bias in ciliate assemblages is very problematic for biodiversity consideration and grazing investigations. Simply changing the method of filling during the experimental set-up can ensure the measurement of accurate grazing rates of field abundances of microzooplankton. We thus recommend using conservative filling approaches like the FTT in experiments, especially when sensitive species are present, in order to avoid shifts in the overall microzooplankton community. Furthermore, we recommend introducing a control to evaluate the degree of changes in the target community due to the experimental set-up.
\end{abstract}

Keywords: ciliates, dilution experiments, dinoflagellates, FTT, microzooplankton, siphoning

Submitted 25 June 2009; accepted 6 December 2009

\section{INTRロDUCTIDN}

As the importance of microzooplankton as fundamental grazers in planktonic food webs became recognized, diverse techniques for determining the grazing impact of microzooplankters were developed (Kivi \& Setälä, 1995). The most widely used method to estimate in situ grazing rates is Landry \& Hassett's dilution technique (Landry \& Hassett, 1982; Calbet \& Landry, 2004) which facilitates the estimation of grazing rates in barely manipulated grazer communities. Consequently, this method is now standard for assessments of in situ grazing rates of smaller microzooplankton $\left(<_{200} \mu \mathrm{m}\right)$.

As part of these experiments, mesozooplankton is removed and samples are checked for screening effectiveness with regard to the mesozooplankton (Fonda Umani et al., 2005) or losses in the phytoplankton fraction. However, to our knowledge no published study has so far considered potential losses of microzooplankton during the set-up of these experiments (Suzuki et al., 2002; Paterson et al., 2008; Pearce et al., 2008). This is especially problematic if the in situ abundance and biodiversity of microzooplankton grazers are the main targets of an experiment and results are transferred to the field.

Corresponding author:

M.G.J. Löder

Email: Martin.Loeder@awi.de
Microzooplankton mainly consists of very delicate organisms (in particular ciliates and dinoflagellates: Gifford, 1985; Suzuki et al., 2002; Broglio et al., 2003), thus manipulation of water samples while setting up grazing experiments could significantly alter the grazer community through the loss of sensitive taxa, affecting estimates of grazing rates. This would defeat the goal of a grazing experiment aimed at the determination of the in situ grazing rate.

To avoid the loss of microzooplankters during the experimental set-up a widely used technique involves the siphoning off of water (Figure $1 \mathrm{~B}$ ) using silicone tubing and leaving the end of the tubing submerged in the water (Stelfox-Widdicombe et al., 2004; Strom et al., 2007; Paterson et al., 2008). This technique prevents destructive air bubbles that can occur in pouring processes (Figure $1 \mathrm{~A}$ ) and is thus believed to conserve fragile species.

In preliminary experiments we found lower abundances of sensitive microzooplankton in siphoned samples when compared to the field, a pattern which was especially true for ciliates. Thus, we hypothesized that the set-up technique (here siphoning) might cause: (1) diminished microzooplankton abundances; (2) pronounced effects on ciliates compared to dinoflagellates; and (3) a selection in species composition in favour of non-sensitive species and thus an artificially modified grazer community. Consequently we compared two gentle filling techniques, siphoning (Figure $1 \mathrm{~B}$ ) versus a modified application, the alternative funnel-transfer technique (FTT) (Figure ${ }_{1} \mathrm{C}$ ) while setting up dilution experiments. 
A

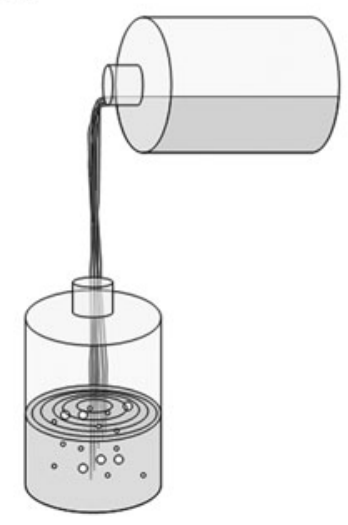

B

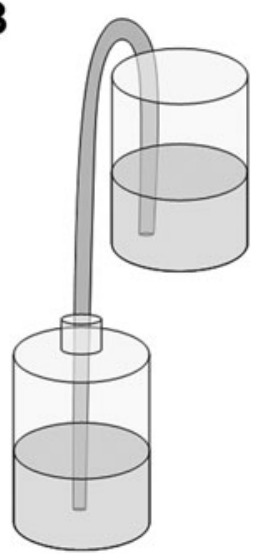

C

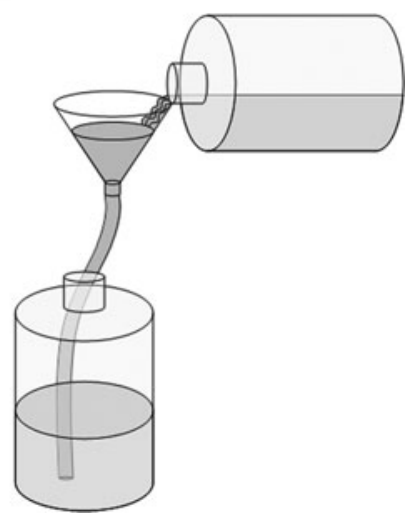

Fig. 1. Illustration of the different filling techniques: (A) a simple, more destructive pouring process producing a lot of air bubbles; (B) siphoning the water via a tube into a container without air bubbles; (C) our new, more gentle approach to fill incubation bottles: combination of a funnel and tube (FTT).

Here, we report the effects of both filling techniques on microzooplankton abundance and Margalef diversity (dinoflagellates and ciliates) of North Sea samples. We concentrate on in situ grazing experiments, but the results are equally applicable to any situation where zooplankton communities containing physically fragile species are to be manipulated in the laboratory.

\section{MATERIALS AND METHDDS}

Two different methods of filling experimental bottles for grazing experiments were tested in two separate experiments using water taken from the North Sea.

\section{Sampling site}

Helgoland is located in the German Bight (southern North Sea) approximately $50 \mathrm{~km}$ off the German coast. It is subject to both coastal influences from the shallow Wadden Sea as well as marine influences from the open North Sea. Since 1962 bucket water samples have been taken as part of a long term monitoring programme at the 'Kabeltonne' site at Helgoland Roads $\left(54^{\circ} 11.3^{\prime} \mathrm{N} 7^{\circ} 54.0^{\prime} \mathrm{E}\right)$ (Wiltshire et al., 2008). Water samples for the experiments were taken here.

\section{Filling techniques}

We compared two filling techniques: siphoning and FTT. Siphoning is believed to be conservative for sensitive species as it avoids bubbling when the flow-end of the tube is kept under the water surface (Stelfox-Widdicombe et al., 2004; Strom et al., 2007; Paterson et al., 2008). Water is transferred only via hydrostatic pressure through a tube from one container to another when both containers have different water levels relative to geodetic height (Figure $1 \mathrm{~B}$ ). The FTT consists of a funnel mounted on a tube. For the transfer to a container, water is filled gently into the funnel keeping the tube compressed completely until the funnel is half-full. Thereafter water flow to the container is adjusted via the internal diameter by compressing the flexible tube compartment (Figure ${ }_{1} \mathrm{C}$ ). This technique also avoids air bubbles that could harm sensitive species.

\section{Experiment 1}

Experiment 1 (July 2007) was conducted to compare the two filling techniques using the experimental set-up of dilution grazing experiments. During the experiment both techniques were tested with a $200 \mu \mathrm{m}$ net for pre-screening. Pre-screening is routine in dilution experiments and excludes mesozooplankton grazers ensuring that only the microzooplankton grazing is measured (Liu \& Dagg, 2003; Fonda Umani et al., 2005; Sakka Hlaili et al., 2007).

Containers, bottles, tubing and other material used for the experiments were acid washed (10\% HCL) and rinsed with deionized water. Approximately 501 of surface seawater were sampled at Helgoland Roads using a bucket and poured without bubbling into a wide-necked carboy. The samples were brought to the laboratory immediately.

The homogeneous distribution of the plankton in the initial seawater was ensured by gentle mixing. After homogenization, 101 were gently transferred into a 101 carboy (as usually used for the set-up of a dilution series) with the FTT (Figure ${ }_{1} \mathrm{C}$ ). Special care was taken during the filling process that no air bubbles were produced. When the carboy was filled, the flow was terminated by compressing the tube. In parallel to the FTT method 101 of seawater were siphoned off with a silicone tube into a separate carboy (Figure $1 \mathrm{~B}$ ). 2.3 1 narrow-necked polycarbonate incubation bottles were filled with water from each corresponding 101 carboy using both methods in three replicates. Before each filling step gentle mixing was carried out. In both approaches a $200 \mu \mathrm{m}$ mesh was fixed at the end of the tube. All incubation bottles were filled to the top, closed and stored cool in the dark until sampling for microzooplankton and chlorophyll- $a$.

\section{Experiment 2}

Experiment 2 (April 2008) was designed to investigate both filling techniques with and without the $200 \mu \mathrm{m}$ pre-screening to record additional effects of the pre-screening process on the monitored parameters.

The experimental set-up in Experiment 2 was as described for Experiment 1 above. Siphoning and the FTT were also applied without pre-screening, resulting in a total of four treatments. Furthermore, a control with pure seawater served as a reference value: water for the determination of chlorophyll- $a$ content and 
microzooplankton species composition was scooped out with a 11 beaker from the initial seawater at the beginning of the experiment. During the set-up of both experiments special care was taken not to produce bubbles.

\section{Determination of microzooplankton species}

A $250 \mathrm{ml}$ aliquot of each incubation bottle was subsampled into amber bottles and immediately fixed at a final concentration of $2 \%$ acid Lugol's iodine solution (Throndsen, 1978). Samples were stored cool and dark until further analysis. For species determination $50 \mathrm{ml}$ samples were settled in Utermöhl sedimentation chambers (HYDRO-BIOS) for 24 hours (Utermöhl, 1958). To reduce a possible counting bias caused by patchy settlement, the whole surface of the sedimentation chamber was counted at 200 -fold magnification under a Zeiss Axiovert 135 inverted microscope. The microzooplankton fractions were considered as two major groups: dinoflagellates and ciliates. Each group was identified to genus or species level or when this was impossible pooled into size-dependent groups or morphotypes. The identification of dinoflagellates was primarily based on Drebes (1974), Dodge (1982) and Tomas (1996). Ciliates were determined based on Kahl (1932) and Montagnes (2003).

\section{Chlorophyll- $a$ analysis}

Filtration of a subsample was carried out in a laboratory under dim light $(<5 \mu$ mol PAR) to avoid the loss of pigments during the filtration procedure. We used the method of extraction and analysis as described by Wiltshire et al. (1998). Pigments were separated via high-performance liquid chromatography (HPLC) (Waters 2695 Separation Module), and detected with a Waters 996 Photodiode Array Detector (Wiltshire et al., 2000).

\section{Data analysis}

The Margalef index ' $d$ ' was calculated for the most abundant ciliate and dinoflagellate species according to Equation (1).

$$
\mathrm{d}=(\mathrm{S}-1) /(\ln \mathrm{N})
$$

This index was chosen as a simple measure for the relationship between total number of species (S) and total abundance of individuals $(\mathrm{N})$ in a sample (Washington, 1984). Therefore, it is a useful tool for the analysis of samples in the present study. If in two samples the total number of species is the same (as in our analysis), then the Margalef index gives direct information about the differences in the total abundance of individuals between the two samples. The index will be lower in the sample with the higher total abundance and therefore reflects changes due to the different filling methods.

Margalef indices, chlorophyll- $a$ contents and abundances of dinoflagellates or ciliates between the treatments in Experiment 1 were tested for significant differences using $t$-tests. Differences between the four treatments and the control sample in Experiment 2 were in a first step analysed using $t$-tests. This was necessary because the control was not influenced by any treatment and could therefore not be included in an ANOVA. The effects of the two filling techniques and the pre-screening process on the above-mentioned parameters as well as the interaction between both were tested using a $2 \times 2$ factorial ANOVA.
Due to the normal count uncertainties of microzooplankton samples and, connected to that, a high variability in abundance of rare species, only dinoflagellate and ciliate species or groups that contained more than 200 cells $1^{-1}$ in one of the two treatments (Experiment 1) or the control (Experiment 2) are shown here. It has been shown that many chloroplast-bearing dinoflagellate species are capable of mixotrophic nutrition via phagotrophy (Tillmann, 2004). Therefore, all dinoflagellate species were considered as potential grazers and were included in the analysis. Statistical analyses were conducted with the software Statistica 7.1 (Stat Soft).

RESULTS

\section{Experiment 1}

\section{MICROZOOPLANKTON}

Microzooplankton was classified into 12 categories of ciliates and 15 categories of dinoflagellates. The microzooplankton community was numerically dominated by dinoflagellates (61\%, FTT).

\section{Ciliates}

The three most abundant ciliate groups were: Myrionecta rubra 'intermediate' (35-50 $\mu \mathrm{m}$ length), scuticociliates and Myrionecta rubra 'small' (15-25 $\mu \mathrm{m}$ length). These three groups accounted for $84 \%$ of the total abundance of the FTT treatment and $77 \%$ of the siphoned treatment (mean values). They therefore dominated the ciliate community. We found a significant ciliate cell loss of $41 \%$ due to siphoning ( $t=3.162$, $\mathrm{df}=4, P=0.034$, two-sided $t$-test) (Figure 2A; Table 1) for pooled values of the three most abundant groups leading to significant changes in diversity. The Margalef index 'd' (Figure $2 \mathrm{~B}$; Table 1) for the three most abundant ciliate groups was significantly lower for the FTT $(t=-2.569, \mathrm{df}=4, P=0.031$, single-sided $t$-test) compared to siphoning. No difference in the Margalef index was observed between both treatments for the whole ciliate community (data not shown).

At species/group level the loss of cells was most pronounced in the category M. rubra 'intermediate'. This sizeclass of $M$. rubra accounted for $54 \%$ of total ciliate cells (FTT) and displayed a significant loss of $56 \%$ in cell numbers in the siphoned treatments $(t=3.483, \mathrm{df}=4, P=$ 0.025 , two-sided $t$-test). The category $M$. rubra 'small' showed a similar pattern to $M$. rubra 'intermediate' with a $34 \%$ lower mean cell number when siphoned. However, this effect was not statistically significant given the large count uncertainties. For the category 'scuticociliates' no significant difference between both treatments could be detected.

Although chlorophyll- $a$ concentrations during our experiment were relatively low $(<0.2 \mu \mathrm{g} / \mathrm{l})$, we detected significant differences between both methods, with lower chlorophyll- $a$ contents in the siphoned treatments $(t=5.366, \mathrm{df}=4, P=$ 0.006 , two-sided $t$-test) (Table 1 ), possibly linked to the loss of $M$. rubra cells.

\section{Dinoflagellates}

Four groups, accounting for $85 \%$ of the total dinoflagellate abundance in both treatments, were used for statistical analysis: thecate dinoflagellates 'small' (20-25 $\mu \mathrm{m}$ length), Scrippsiella sp., Gyrodinium sp. intermediate' $(30-50 \mu \mathrm{m}$ length) and Torodinium sp. (Table 1). In contrast to 

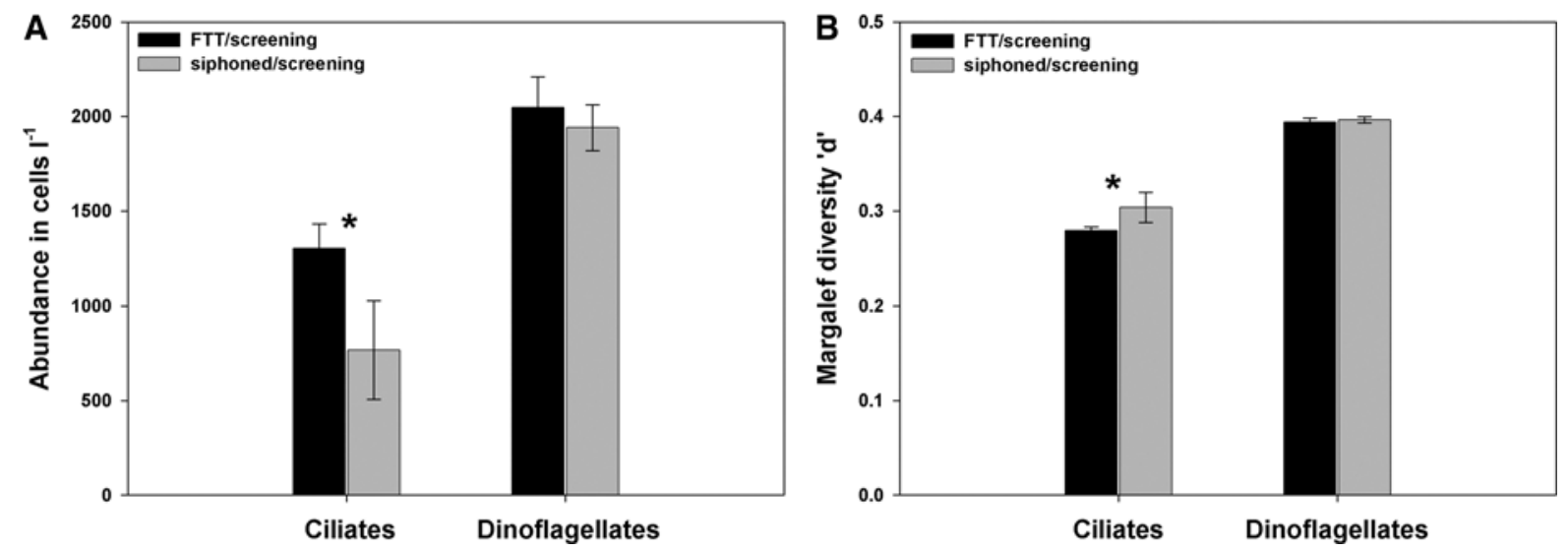

Fig. 2. Experiment 1. (A) Mean abundance and (B) Margalef diversity 'd' of the most abundant ciliate and dinoflagellate species. Both treatments were done using a $200 \mu \mathrm{m}$ pre-screened natural seawater sample. Significant difference marked with asterisk. Error bars correspond to one standard deviation.

observations for the most abundant ciliate categories, we found no differences between the two treatments for the four most abundant dinoflagellate groups pooled together or at species level (Figure 2A; Table 1). Margalef indices 'd' calculated for the four most abundant and all dinoflagellate categories also revealed no differences in abundance for both treatments (Figure $2 \mathrm{~B}$; Table 1 ).

\section{Experiment 2}

\section{MICROZOOPLANKTON}

In the second experiment 21 categories were established for ciliates and dinoflagellates corresponding to different species, group or size-classes. Ciliates numerically dominated the microzooplankton community (60\%, control).

Table 1. Percentage of loss based on abundances of the most common ciliate and dinoflagellate groups, chlorophyll- $a$ contents and Margalef indices ' $d$ ' during siphoning compared to the FTT for Experiment 1 ( 4 July 2007). $P$ values derived from double-sided $t$-tests $(\mathrm{N}=3)$. n.s., not significant $(P>0.05)$. ${ }^{*} P$ value derived from single-sided $t$-test.

\begin{tabular}{|c|c|c|c|}
\hline \multirow[t]{2}{*}{ Comparison of treatments } & \multicolumn{3}{|c|}{ Siphoned-200 $\mu \mathrm{m}$ screening } \\
\hline & $\begin{array}{l}\text { Abundance } \\
\text { compared } \\
\text { to FTT }\end{array}$ & $\begin{array}{l}\text { Loss } \\
\text { compared } \\
\text { to FTT }\end{array}$ & $\begin{array}{l}P \\
\text { value }\end{array}$ \\
\hline \multicolumn{4}{|l|}{ Ciliates } \\
\hline $\begin{array}{l}\text { Myrionecta rubra } \\
\text { 'intermediate' }\end{array}$ & $44.0 \%$ & $56.0 \%$ & 0.025 \\
\hline Scuticociliates & $102.6 \%$ & $-2.6 \%$ & n.s. \\
\hline Myrionecta rubra 'small' & $65.6 \%$ & $34.4 \%$ & n.s. \\
\hline Sum 3 most abundant ciliates & $59.0 \%$ & $41.0 \%$ & 0.034 \\
\hline \multicolumn{4}{|l|}{ Dinoflagellates } \\
\hline Thecate dinoflagellates 'small' & $96.9 \%$ & $3.1 \%$ & n.s. \\
\hline Scrippsiella sp. & $77.9 \%$ & $22.1 \%$ & n.s. \\
\hline Gyrodinium sp. 'intermediate' & $103.4 \%$ & $-3.4 \%$ & n.s. \\
\hline Torodinium sp. & $126.9 \%$ & $-26.9 \%$ & n.s. \\
\hline $\begin{array}{l}\text { Sum } 4 \text { most abundant } \\
\text { dinoflagellates }\end{array}$ & $94.8 \%$ & $5.2 \%$ & n.s. \\
\hline Chlorophyll- $a$ & $75.3 \%$ & $24.7 \%$ & 0.006 \\
\hline \multicolumn{4}{|l|}{ Margalef diversity 'd' } \\
\hline Sum 3 most abundant ciliates & $108.6 \%$ & $-8.6 \%$ & $0.031^{*}$ \\
\hline $\begin{array}{l}\text { Sum } 4 \text { most abundant } \\
\text { dinoflagellates }\end{array}$ & $100.5 \%$ & $-0.5 \%$ & n.s. \\
\hline
\end{tabular}

\section{Ciliates}

Ciliate categories that presented abundances above 200 cells $1^{-1}$ were: Lohmanniella oviformis, Strombidium cf. tressum, Strombidium cf. epidemum, Balanion comatum and Myrionecta rubra 'small' (15-25 $\mu \mathrm{m}$ length). The five ciliate categories grouped together made up over $80 \%$ of the total ciliates' community in all treatments.

In a first step we pooled together the top five abundant ciliates and carried out a single-sided $t$-test (Table 2). It revealed a significant, $13 \%$ decline in abundance $(t=2.390, \mathrm{df}=4, P=$ 0.038 ) when siphoned without pre-screening compared to the control, while the FTT without pre-screening showed no difference. Both treatments with additional pre-screening exhibited significant losses in cell numbers compared to the control (siphon technique: mean loss of $26 \%, t=4.820$, $\mathrm{df}=4, P=0.004 ;$ FTT: mean loss $19 \%, t=3.927, \mathrm{df}=4$, $P=0.009$, single-sided $t$-tests).

In the two-factorial ANOVA pooled abundances of the five most abundant ciliates showed significantly lower cell

Table 2. Percentage of loss in abundance of the most abundant ciliate and dinoflagellate groups due to the different treatments and treatment combinations compared to the control values during Experiment 2 (1 April 2008). $P$ values derived from single-sided $t$-tests $(\mathrm{N}=3)$. n.s., not significant $(P>0.05)$.

\begin{tabular}{llllll}
\hline $\begin{array}{l}\text { Comparison of } \\
\text { treatments }\end{array}$ & Siphoned & & FTT & \\
\cline { 2 - 3 } \cline { 5 - 6 } & $\begin{array}{l}\text { Loss } \\
\text { compared } \\
\text { to control }\end{array}$ & $\begin{array}{l}\boldsymbol{P} \\
\text { value }\end{array}$ & $\begin{array}{l}\text { Loss } \\
\text { compared } \\
\text { to control }\end{array}$ & $\begin{array}{l}\boldsymbol{P} \\
\text { value }\end{array}$ \\
\hline $\begin{array}{c}\text { Sum } 5 \text { most abundant } \\
\text { ciliates }\end{array}$ & $13.3 \%$ & 0.038 & $-0.7 \%$ & n.s. \\
Sum 4 most abundant & $0.0 \%$ & n.s. & $-13.8 \%$ & n.s.
\end{tabular}

$$
\text { dinoflagellates }
$$

Comparison of $\quad$ Siphoned-200 $\mu \mathrm{m} \quad$ FTT $-200 \mu \mathrm{m}$

treatments screening screening

$\begin{array}{llll}\text { Loss } & P & & \\ \text { Loss }\end{array}$

$\begin{array}{llll}\text { Loss } & P & \text { Loss } & P \\ \text { compared } & \text { value } & \text { compared } & \text { value }\end{array}$

compared value compared value to control to control

\begin{tabular}{lcccc}
\hline $\begin{array}{c}\text { Sum } 5 \text { most abundant } \\
\text { ciliates }\end{array}$ & $25.9 \%$ & 0.004 & $19.2 \%$ & 0.009 \\
$\begin{array}{c}\text { Sum } 4 \text { most abundant } \\
\text { dinoflagellates }\end{array}$ & $-1.3 \%$ & n.s. & $-12.5 \%$ & n.s. \\
\hline
\end{tabular}


concentrations after siphoning $\left(\mathrm{F}_{1,8}=6.685, P=0.03\right)$ and pre-screening $\left(\mathrm{F}_{1,8}=16.508, \mathrm{P}=0.004\right)$ as compared to the FTT and no screening, respectively (Figure $3 \mathrm{~A}+\mathrm{B}$; Table 3), leading in both cases to significant changes in diversity. The Margalef index ' $d$ ' (Table 3; Figure $3 \mathrm{C}+\mathrm{D}$ ) showed no difference at the community level (data not shown) but was significantly lower for the five most abundant ciliate species when 'no pre-screening' took place $\left(\mathrm{F}_{1,8}=19.0, P=0.002\right)$. Similar to Experiment 1, the Margalef index 'd' was also lower for the FTT $\left(\mathrm{F}_{1,8}=7.4, P=0.026\right.$; Table 3$)$. No significant treatment interactions were observed for either abundances or Margalef index.

At the species level our results could be ascribed to the two dominant ciliates. Lohmanniella oviformis, showed a significant cell loss $\left(17 \%, \mathrm{~F}_{1,8}=14.173, P=0.006\right)$ after siphoning as well as after pre-screening (loss: $13 \%, \mathrm{~F}_{1,8}=7.471, P=$ o.026). For Strombidium cf. tressum no significant difference between both filling treatments was found but pre-screening resulted in a significant loss of cells (up to $51 \%$ cell loss, $\left.\mathrm{F}_{1,8}=56.3325, P=0.00007\right)$. The interaction of both filling methods and pre-screening showed a significant negative effect $\left(\mathrm{F}_{1,8}=6.4228, P=0.035\right)$ on $S$. cf. tressum with a stronger reduction in cell numbers when the combination of the FTT and pre-screening was used. The other three important ciliate species (Strombidium cf. epidemum, Balanion comatum and Myrionecta rubra 'small') were not significantly affected by any treatment. With a mean concentration of $\sim 1.3 \mu \mathrm{g} / \mathrm{l}$ the chlorophyll- $a$ content was approximately 10 fold higher in Experiment 2 as compared to Experiment 1. However, the differences between the treatments were not as clear as in Experiment 1.

\section{Dinoflagellates}

The four most abundant dinoflagellate categories were considered for analyses: athecate dinoflagellates 'intermediate' (25-40 $\mu \mathrm{m}$ length), Gyrodinium sp. 'intermediate' (30$50 \mu \mathrm{m}$ length), Protoperidinium bipes and Torodinium sp. These four species contributed $82 \%$ to the dinoflagellate community. As in Experiment 1, no differences in abundance were found when the four dinoflagellate groups pooled were compared to the control (Table 2). For the pooled group an ANOVA proved insignificant (Figure $3 \mathrm{E}+\mathrm{F}$; Table 3 ) for the treatments as well as their interaction. At species level the athecate dinoflagellates 'intermediate' revealed significantly lower cell numbers in the siphoned treatment $\left(\mathrm{F}_{1,8}=\right.$ 8.2718, $P=0.02$; Table 3) as compared to the FTT. No impact of the pre-screening process or the combination of treatment and pre-screening on the other dinoflagellates could be found. As in Experiment 1, no differences were found for the Margalef index ' $d$ ' calculated for the whole community (data not shown) or when considering only the five most abundant groups (Table 3; Figure $3 \mathrm{G}+\mathrm{H}$ ).

\section{DISCUSSIDN}

\section{Transfer technique}

The main aim of this study was to determine whether filling and screening techniques can influence abundance and diversity of microzooplankton during the set-up of grazing experiments. Although the FTT superficially seems to represent only a marginal modification of siphoning the change has a significant effect on microzooplankton diversity. Overall, siphoning significantly reduced the abundance of ciliates in North Sea water, while the dinoflagellate community seemed to be unaffected. The lower impact on the ciliate community using the FTT was reflected in the lower Margalef index ' $d$ ' for the most abundant ciliates in both experiments. The abundance and Margalef index 'd' of both microzooplankton groups were found to be similar to the control (Experiment 2) when the FTT was used, indicating that in contrast to siphoning no significant effect occurred using the FTT.

While the overall ciliate numbers appeared to be lower when siphoning was used, this was statistically significant only for two of the dominant ciliate species: Myrionecta rubra and Lohmanniella oviformis. The taxa Lohmanniella and $M$. rubra are widely distributed in coastal and open ocean environments (Smetacek, 1984; Kivi \& Setälä, 1995; Myung et al., 2006; Park et al., 2007) and are also important members of the microzooplankton community in the North Sea around Helgoland (Figure 4). Both are known to feed on nanoplankton (Jonsson, 1986; Christaki et al., 1998; Aberle et al., 2007; Park et al., 2007) and bacteria (Myung et al., 2006).

Both ciliates can be considered important grazers in temperate waters in general and dominated the communities during our experiments. Therefore, retaining natural abundances is important for accurate estimations of microzooplankton grazing.

In contrast to ciliates the sensitivity of dinoflagellates to the transfer method was more variable and species-dependent. Our results show that only the most abundant dinoflagellate group (athecate dinoflagellates 'intermediate') in Experiment 2 was significantly affected by siphoning. No effect was detected for all other investigated species. Heterotrophic dinoflagellates, including both thecate and athecate species are microzooplankton grazers of global importance (Tillmann, 2004) frequently contributing more than $50 \%$ to the microzooplankton biomass (Sherr \& Sherr, 2007). As they often occur at high abundances during diatom blooms and are known to be more efficient grazers of bloom-forming diatoms than copepods and other mesozooplankters (Sherr \& Sherr, 2007) it is vital not to lose dinoflagellates during grazing experiment set-ups.

Our results also show that siphoning can affect chlorophyll- $a$ concentration when setting up experiments. It has been reported that mixotrophic ciliates like Myrionecta rubra dominate plankton assemblages at certain times of the year (Stoecker et al., 1987). This was also the case during Experiment 1 (Figure 4). Our results show that the loss of these mixotrophic cells due to siphoning may induce an additional bias into dilution experiments through the concomitant loss of chlorophyll- $a$, a commonly used estimate for overall phytoplankton biomass.

The effect of siphoning on microzooplankton might be explained by hydro-mechanical disturbance of water when using this method. Mechanoreceptors are common in planktonic organisms (Singarajah, 1969; Titelman \& Kiørboe, 2003; Robinson et al., 2007), including ciliates (Buskey \& Stoecker, 1989; Jakobsen, 2001, 2002; Jakobsen et al., 2006) and dinoflagellates (Jakobsen et al., 2006). Different ciliates are reported to respond with long jumps to siphon-simulated feeding currents (Jakobsen, 2001; Fenchel \& Hansen, 2006) and to orientate themselves against the current in a siphon flow (Fenchel \& Hansen, 2006). They also respond with escape during the isolation processes with a pipette (tip: $1 \mathrm{~mm}$ diameter) 

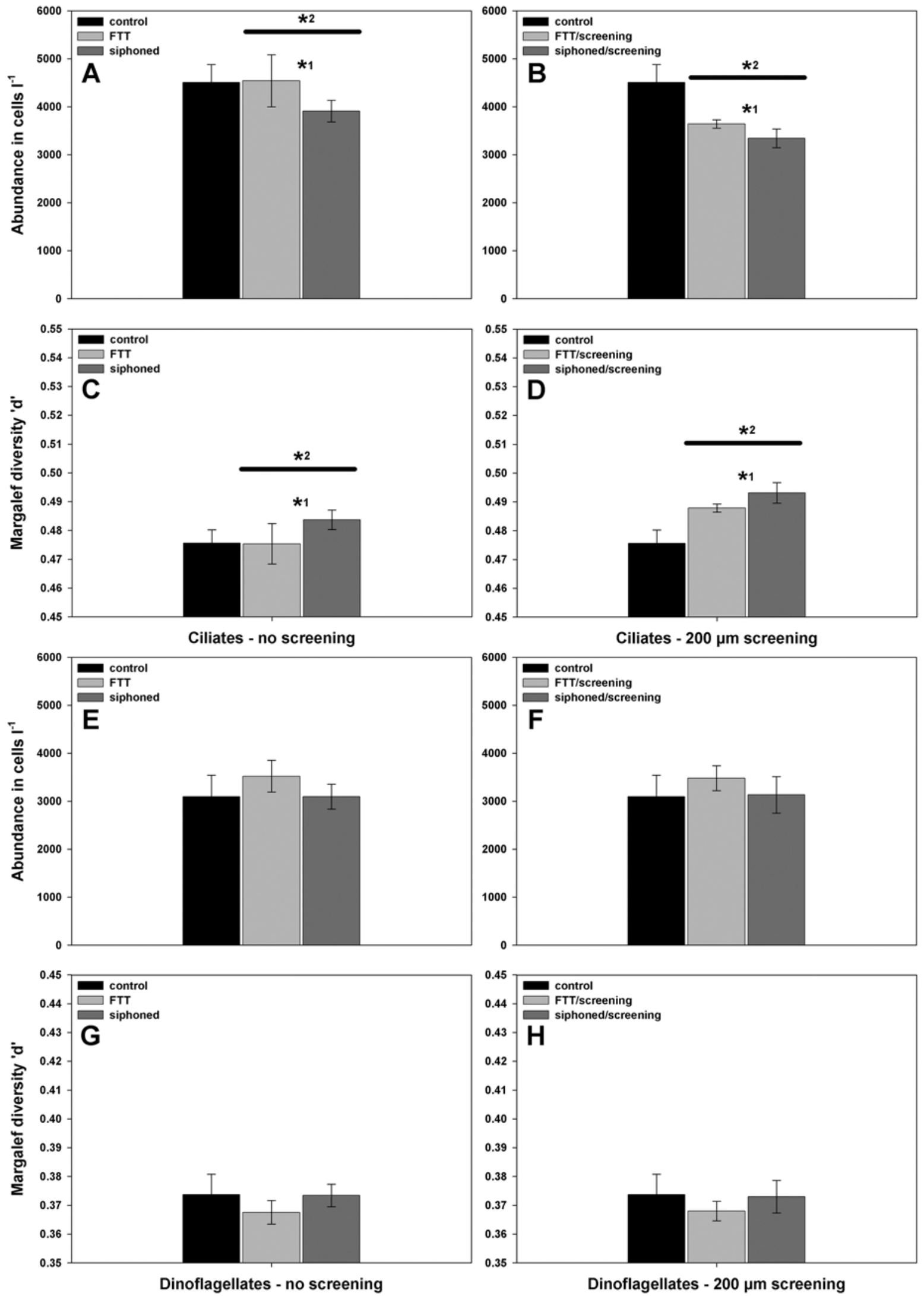

Fig. 3. Experiment 2. (A, B) Mean abundance of the most abundant ciliate species, (E, F) mean abundance of the most abundant dinoflagellate species and (C, D, $\mathrm{G}, \mathrm{H}$ ) corresponding Margalef diversity 'd' in the control and using the FTT or the siphoning technique in experiments without (A, C, E, G) or with pre-screening with a $200 \mu \mathrm{m}$ net (B, D, F, H). Control treatments were obtained by scooping samples from the initial seawater without pre-screening. Significant differences are marked with asterisks. Asterisk ${ }^{* 1}$ symbolizes significant differences between siphoning and the FTT; asterisk ${ }^{* 2}$ on the top of the horizontal bar symbolizes differences between 'pre-screening' and 'no pre-screening' independently from the filling technique used (therefore compare bars under the horizontal bar for each filling treatment in A and B, C and D). Error bars correspond to one standard deviation. 
Table 3. Percentage of loss in abundance of the most abundant ciliate and dinoflagellate species, chlorophyll- $a$ contents and Margalef indices ' $\mathrm{d}$ ' due to siphoning in comparison to the FTT and pre-screening in comparison to no pre-screening and effects of the combination between pre-screening and treatment during Experiment 2 (1 April 2008). $P$ values are derived from ANOVA comparing all treatments $(\mathrm{N}=6)$. n.s., not significant $(P>0.05)$;

${ }^{a}$ significantly lower abundance in the FTT with pre-screening treatments; ${ }^{b}$ significantly higher content in the FTT with pre-screening treatments.

\begin{tabular}{|c|c|c|c|c|c|c|}
\hline \multirow[t]{2}{*}{ Comparison of treatments } & \multicolumn{2}{|l|}{ Siphoned } & \multicolumn{2}{|l|}{ Screening } & \multicolumn{2}{|c|}{$\begin{array}{l}\text { Screening } \times \\
\text { treatment }\end{array}$} \\
\hline & $\begin{array}{l}\text { Loss compared } \\
\text { to FTT }\end{array}$ & $P$ value & $\begin{array}{l}\text { Loss compared to } \\
\text { no screening }\end{array}$ & $P$ value & - & $P$ value \\
\hline \multicolumn{7}{|l|}{ Ciliates } \\
\hline Lohmanniella oviformis & $16.9 \%$ & 0.006 & $12.6 \%$ & 0.026 & & n.s. \\
\hline Strombidium cf. tressum & $11.6 \%$ & n.s. & $50.7 \%$ & 0.00007 & & $0.035^{\mathrm{a}}$ \\
\hline Strombidium cf. epidemum & $3.1 \%$ & n.s. & $9.7 \%$ & n.s. & & n.s. \\
\hline Balanion comatum & $10.3 \%$ & n.s. & $2.8 \%$ & n.s. & & n.s. \\
\hline Myrionecta rubra 'small' & $9.2 \%$ & n.s. & $-11.8 \%$ & n.s. & & n.s. \\
\hline Sum 5 most abundant ciliates & $11.4 \%$ & 0.032 & $17.4 \%$ & 0.0036 & & n.s. \\
\hline \multicolumn{7}{|l|}{ Dinoflagellates } \\
\hline Athecate dinoflagellates 'intermediate' & $17.6 \%$ & 0.021 & $-2.7 \%$ & n.s. & & n.s. \\
\hline Gyrodinium sp. 'intermediate’ & $14.6 \%$ & n.s. & $19.7 \%$ & n.s. & & n.s. \\
\hline Protoperidinium bipes & $-17.9 \%$ & n.s. & $-17.9 \%$ & n.s. & & n.s. \\
\hline Torodinium sp. & $-15.2 \%$ & n.s. & $2.8 \%$ & n.s. & & n.s. \\
\hline Sum 4 most abundant dinoflagellates & $11.0 \%$ & n.s. & $0.0 \%$ & n.s. & & n.s. \\
\hline Chlorophyll- $a$ & $7.2 \%$ & $0.0025^{\mathrm{b}}$ & $2.6 \%$ & n.s. & & $0.027^{\mathrm{b}}$ \\
\hline \multicolumn{7}{|l|}{ Margalef diversity 'd' } \\
\hline Sum 5 most abundant ciliates & $-1.4 \%$ & 0.026 & $-2.3 \%$ & 0.002 & & n.s. \\
\hline Sum 4 most abundant dinoflagellates & $-1.5 \%$ & n.s. & $0.002 \%$ & n.s. & & n.s. \\
\hline
\end{tabular}

during culture attempts (Löder, personal observation). Although the siphon-tube diameter $(7 \mathrm{~mm})$ we used was bigger than that used by Jakobsen (2001) $(0.25-0.48 \mathrm{~mm})$, the flow velocity and therefore also the shear stress around the tube tip was in the same order of magnitude as that of Jakobsen (2001). The ability of ciliates to detect suction at the top of a tube and respond with escape is reported by Jakobsen (2002) and could explain their lower numbers in the incubation bottles when siphoning was used. Interestingly along with Lohmanniella oviformis only the larger Myrionecta rubra 'intermediate' cells were significantly affected by the siphon technique, whereas no significant difference was found for the category M. rubra 'small'. This could be linked to the ability of the larger M. rubra to perform longer escape jumps than the smaller, which probably enables them to escape the siphon suction more successfully.

Similar to ciliates, mechanoreceptors that enable predator detection have also been described for dinoflagellates (Maldonado \& Latz, 2007). Jakobsen et al. (2006) reported highly effective escape behaviour for two different dinoflagellates when being attacked by a predator. Although the differences were less obvious for dinoflagellates, siphoning had an effect on one naked dinoflagellate species in Experiment 2. These differences could also be due to the same predator detection and escape behaviour as described above for ciliates.

The high fragility of microzooplankton could also be an explanation for the effect of siphoning on some ciliate species (Gifford, 1985; Suzuki et al., 2002; Broglio et al., 2003). During the passage of the organism through the tube

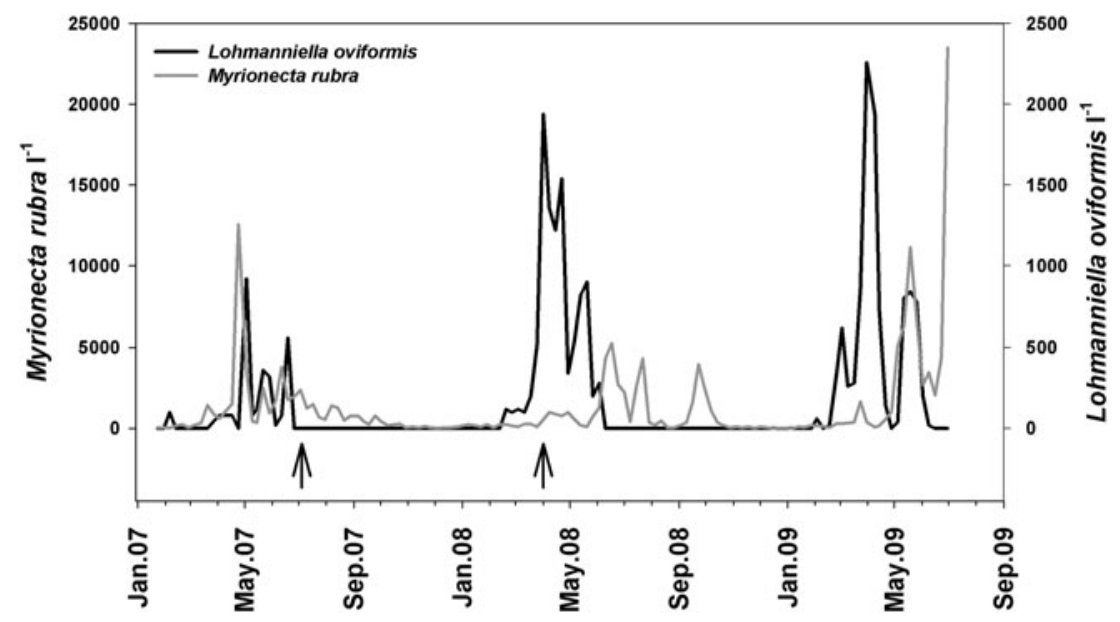

Fig. 4. Abundance of Myrionecta rubra and Lohmanniella oviformis during a 2.5 year period. Values from a weekly monitoring programme ( $\mathrm{N}=128$ ). Arrows mark dates of the two experiments. 
physical stress is likely to act on the organism and the period of time the organism is exposed to that should increase with the length of the tubing. Necessarily, siphoning requires a longer tube compared to FTT and could therefore also cause greater damage in fragile species.

Importantly, the error introduced by the siphoning technique in our experiments was not uniform across taxa. If experiments are replicated at different times of the year this could potentially lead to a different source of error in every single experiment depending on the community structure present leading to difficulties in comparison.

\section{Pre-screening}

Several authors recommend not using pre-screening for dilution experiments to avoid retention of phytoplankton chains or breakage of the cells. Our results also show that prescreening had an effect on ciliates. This effect was stronger than the effect of siphoning as it led to a greater loss of ciliates at species level. Importantly, different ciliate species did not respond uniformly to pre-screening. A negative effect of prescreening on fragile ciliates due to mechanical shear forces has been reported previously (Gifford, 1985) and could be shown here for Strombidium cf. tressum and more moderately for the strobilid Lohmanniella oviformis. The reduced abundance of ciliates resulted in a higher Margalef index (Table 3) compared to the unscreened treatments. The difference in response to the pre-screening process could indicate different degrees of fragility in ciliates, even in the same genus such as Strombidium cf. tressum and Strombidium cf. epidemum. Both ciliates are almost in the same size-range (25-40 $\mu \mathrm{m}$ maximal length) but the impact on $S$. cf. tressum was large while $S$. cf. epidemum was not significantly affected. The impact on $S$. cf. tressum ( $51 \%$ loss) was very strong taking into account that the mesh size was $200 \mu \mathrm{m}$ and therefore at least five times the size of the biggest individuals of this species. Compared to the loss rates of oligotrichs due to $202 \mu \mathrm{m}$ screening $(23-37 \%)$ published by Gifford (1985) our results for the pool of the most abundant ciliates are almost in the same size-range $(17 \%)$. In contrast to the ciliates, no effect of the pre-screening process was detectable on dinoflagellates. To our knowledge no work has been published on whether dinoflagellates are sensitive to pre-screening. Despite the observed effect of pre-screening due to a high loss of particular ciliate species, the $200 \mu \mathrm{m}$ pre-screening process remains unavoidable whenever mesozooplankton grazers are present in the water column in high numbers in order to prevent trophic cascade effects and to ensure correct estimates of microzooplankton grazing impact alone.

\section{CロNCLUSIDNS}

We have demonstrated that care is required when setting up grazing experiments particularly when sensitive species are present. Commonly used techniques such as siphoning can reduce microzooplankton abundance and diversity. Siphoning had a negative effect on ciliates compared to dinoflagellates resulting in shifts in species composition and producing an 'artificial' community that did not realistically reflect the in situ situation. Therefore, extrapolations to the field are difficult.
The FTT presented here was shown to be a good alternative to siphoning, conserving the natural microzooplankton abundance and diversity. Negative effects of pre-screening on natural microzooplankton communities were determined. With the methods currently available this cannot be avoided if mesozooplankters are to be excluded. We, therefore, highly recommend the use of a control sample taken from the initial seawater during experiments whenever a loss of species is expected. This enables the evaluation of possible biases in abundances and diversity, especially of ciliates, introduced by the pre-screening or filling techniques. We recommend the use of conservative techniques such as FTT during in situ grazing experiments when sensitive microzooplankton is present. This technique maintains the natural grazer community more closely and thus enables an accurate estimation of the grazing rate.

\section{ACKNOWLEDGEMENTS}

This study was part of a PhD thesis within the Food Web Project at the Alfred-Wegener-Institute for Polar and Marine Research and we are grateful for the funding. We want to thank David Montagnes for help with the identification of ciliates, the crew of the RV 'Aade', Kristine Carstens, Silvia Peters and last but not least the whole team of the AWI Food Web Project for helpful comments on this manuscript.

\section{REFERENCES}

Aberle N., Lengfellner K. and Sommer U. (2007) Spring bloom succession, grazing impact and herbivore selectivity of ciliate communities in response to winter warming. Oecologia 150, 668-681.

Broglio E., Jónasdóttir S.H., Calbet A., Jakobsen H.H. and Saiz E. (2003) Effect of heterotrophic versus autotrophic food on feeding and reproduction of the calanoid copepod Acartia tonsa: relationship with prey fatty acid composition. Aquatic Microbial Ecology 31, 267-278.

Buskey E.J. and Stoecker D.K. (1989) Behavioral responses of the marine tintinnid Favella sp. to phytoplankton: influence of chemical, mechanical and photic stimuli. Journal of Experimental Marine Biology and Ecology 132, 1-16.

Calbet A. and Landry M.R. (2004) Phytoplankton growth, microzooplankton grazing, and carbon cycling in marine systems. Limnology and Oceanography 49, 51-57.

Christaki U., Dolan J.R., Pelegri S. and Rassoulzadegan F. (1998) Consumption of picoplankton-size particles by marine ciliates: effects of physiological state of the ciliate and particle quality. Limnology and Oceanography 43, 458-464.

Dodge J.D. (1982) Marine dinoflagellates of the British Isles. London: Her Majesty's Stationery Office.

Drebes G. (1974) Marines phytoplankton-Eine Auswahl der Helgoländer Planktonalgen (Diatomeen, Peridineen). Stuttgart: Georg Thieme Verlag.

Fenchel T. and Hansen P.J. (2006) Motile behaviour of the bloom-forming ciliate Mesodinium rubrum. Marine Biology Research 2, 33-40.

Fonda Umani S., Tirelli V., Beran A. and Guardiani B. (2005) Relations between microzooplankton and mesozooplankton: competition versus predation on natural assemblages of the Gulf of Trieste (northern Adriatic Sea). Journal of Plankton Research 27, 973-986. 
Gifford D.J. (1985) Laboratory culture of marine planktonic oligotrichs (Ciliophora, Oligotrichida). Marine Ecology Progress Series 23, 257- 267.

Jakobsen H.H. (2001) Escape response of planktonic protists to fluid mechanical signals. Marine Ecology Progress Series 214, 67-78.

Jakobsen H.H. (2002) Escape of protists in predator-generated feeding currents. Aquatic Microbial Ecology 26, 271-281.

Jakobsen H.H., Everett L.M. and Strom S.L. (2006) Hydromechanical signaling between the ciliate Mesodinium pulex and motile protist prey. Aquatic Microbial Ecology 44, 197-206.

Jonsson P.R. (1986) Particle size selection, feeding rates and growth dynamics of marine planktonic oligotrichous ciliates (Ciliophora: Oligotrichina). Marine Ecology Progress Series 33, 265-277.

Kahl A. (1932) Urtiere oder Protozoa. I: Wimpertiere oder Ciliata (Infusoria). 3 Spirotricha. In Dahl F. (ed.) Die Tierwelt Deutschlands und der angrenzenden Meeresteile nach ihrem Merkmalen und ihrer Lebensweise. Jena: Gustav Fischer Verlag, pp. 399-650. [18. Teil]

Kivi K. and Setälä O. (1995) Simultaneous measurement of food particle selection and clearance rates of planktonic oligotrich ciliates (Ciliophora: Oligotrichina). Marine Ecology Progress Series 119, $125-137$.

Landry M.R. and Hassett R.P. (1982) Estimating the grazing impact of marine micro-zooplankton. Marine Biology 67, 283-288.

Liu H. and Dagg M. (2003) Interactions between nutrients, phytoplankton growth and micro- and mesozooplankton grazing in the plume of the Mississippi River. Marine Ecology Progress Series 258, 31-42.

Maldonado E.M. and Latz M.I. (2007) Shear-stress dependence of dinoflagellates bioluminescence. Biological Bulletin. Marine Biological Laboratory, Woods Hole 212, 242-249.

Montagnes D.J.S. (2003) Planktonic ciliate project internet homepage. http://www.liv.ac.uk/ciliate/intro.htm. Accessed: 19 December 2007, time: $13: 56$.

Myung G., Yih W., Kim H.S., Park J.S. and Cho B.C. (2006) Ingestion of bacterial cells by the marine photosynthetic ciliate Myrionecta rubra. Aquatic Microbial Ecology 44, 175-180.

Park J.S., Myung G., Kim H.S., Cho B.C. and Yih W. (2007) Growth responses of the marine photosynthetic ciliate Myrionecta rubra to different cryptomonad strains. Aquatic Microbial Ecology 48, 83-9o.

Paterson H.L., Knott B., Koslow A.J. and Waite A.M. (2008) The grazing impact of microzooplankton off south west Western Australia: as measured by the dilution technique. Journal of Plankton Research 30, 379-392.

Pearce I., Davidson A.T., Wright S. and Van den Enden R. (2008) Seasonal changes in phytoplankton growth and microzooplankton grazing at an Antarctic coastal site. Aquatic Microbial Ecology 50, $157-167$

Robinson H.E., Finelli C.M. and Buskey E.J. (2007) The turbulent life of copepods: effects of water flow over a coral reef on their ability to detect and evade predators. Marine Ecology Progress Series 349, $171-181$.

Sakka Hlaili A., Grami B., Hadj Mabrouk H., Gosselin M. and Hamel D. (2007) Phytoplankton growth and microzooplankton grazing rates in a restricted Mediterranean lagoon (Bizerte Lagoon, Tunisia). Marine Biology 151, 767-783.

Sherr E.B. and Sherr B.F. (2007) Heterotrophic dinoflagellates: a significant component of microzooplankton biomass and major grazers of diatoms in the sea. Marine Ecology Progress Series 352, 187-197.
Singarajah K.V. (1969) Escape reactions of zooplankton: the avoidance of a pursing siphon tube. Journal of Experimental Marine Biology and Ecology 3, 171-178.

Smetacek V. (1984) Growth dynamics of a common Baltic protozooplankter: the ciliate genus Lohmanniella. Limnologica 15, 371-376.

Stelfox-Widdicombe C.E., Archer S.D., Burkill P.H. and Stefels J. (2004) Microzooplankton grazing in Phaeocystis and diatomdominated waters in the southern North Sea in spring. Journal of Sea Research 51, 37-51.

Stoecker D.K., Michaels A.E. and Davis L.H. (1987) Large proportion of marine planktonic ciliates found to contain functional chloroplasts. Nature 326, 790-792.

Strom S.L., Macri E.L. and Olson M.B. (2007) Microzooplankton grazing in the coastal Gulf of Alaska: variations in top-down control of phytoplankton. Limnology and Oceanography 52, 1480-1494.

Suzuki K., Tsuda A., Kiyosawa H., Takeda S., Nishioka J., Saino T., Takahashi M. and Wong C.S. (2002) Grazing impact of microzooplankton on a diatom bloom in a mesocosm as estimated by pigmentspecific dilution technique. Journal of Experimental Marine Biology and Ecology 271, 99-120.

Throndsen J. (1978) Preservation and storage. In Sournia A. (ed.) Phytoplankton manual. Paris: UNESCO, pp. 69-74.

Tillmann U. (2004) Interactions between planktonic microalgae and protozoan grazers. Journal of Eukaryotic Microbiology 51, 156-168.

Titelman J. and Kiørboe T. (2003) Predator avoidance by nauplii. Marine Ecology Progress Series 247, 137-149.

Tomas C.R. (1996) Identifying marine diatoms and dinoflagellates. San Diego, New York, Boston, London, Tokyo, Toronto: Academic Press Inc.

Utermöhl H. (1958) Zur Vervollkommnung der quantitativen Plankton-Methodik. Mitteilung der Internationalen Vereinigung für Theoretische und Angewandte Limnologie 9, 1-38.

Washington H.G. (1984) Diversity, biotic and similarity indices-a review with special relevance to aquatic ecosystems. Water Research $18,653-694$.

Wiltshire K.H., Harsdorf S., Smidt B., Blöcker G., Reuter R. and Schroeder F. (1998) The determination of algal biomass (as chlorophyll) in suspended matter from the Elbe estuary and the German Bight: a comparison of high-performance liquid chromatography, delayed fluorescence and prompt fluorescence methods. Journal of Experimental Marine Biology and Ecology 222, 113-131.

Wiltshire K.H., Boersma M., Möller A. and Buhtz H. (2000) Extraction of pigments and fatty acids from the green alga Scenedesmus obliquus (Chlorophyceae). Aquatic Ecology 34, 119-126.

and

Wiltshire K.H., Malzahn A.M., Wirtz K., Greve W., Janisch S., Mangelsdorf P., Manly B.F., Boersma M. (2008) Resilience of North Sea phytoplankton spring bloom dynamics: An analysis of the long-term data at Helgoland Roads. Limnology and Oceanography $53,1294-1302$.

Correspondence should be addressed to: M.G.J. Löder Biologische Anstalt Helgoland Alfred-Wegener-Institute for Polar and Marine Research Marine Station, POB 180, 27483

Helgoland, Germany email: Martin.Loeder@awi.de 